\title{
Stereostructure of Komodoquinone A, a Neuritogenic Anthracycline, from Marine Streptomyces sp. KS3
}

\author{
Takuya Itoh, Masahiro Kinoshita, Hong Wei, and Motomasa KobaYashi* \\ Graduate School of Pharmaceutical Sciences, Osaka University; 1-6 Yamada-oka, Suita, Osaka 565-0871, Japan. \\ Received August 1, 2003; accepted September 24, 2003
}

The absolute stereostructure of komodoquinone A (1), a neuritogenic anthracycline, which was isolated from a cultured marine Streptomyces sp. KS3, has been determined on the basis of chemical derivatization. Komodoquinone A (1) induces neuronal cell differentiation in the neuroblastoma cell line, Neuro $2 \mathrm{~A}$ and arrests the cell cycle at the G1 phase. The effect of a solid-state medium on the production of 1 and its aglycone, komodoquinone B (2), was examined.

Key words komodoquinone A; anthracycline; Neuro 2A; marine; Streptomyces sp.; neuritogenic activity

A growing number of biologically active metabolites have been explored from marine microorganisms during the past two decades. In recent years, marine microorganisms are paid much attention as a prodigious source for novel drug discovery. ${ }^{1-4)}$ In the course of our project searching for new bioactive substances from marine organisms, ${ }^{5,6)}$ we found a novel anthracycline named komodoquinone $\mathrm{A}$ (1) and its aglycone, komodoquinone B (2), from the solid-state fermentation (solid medium based on rice) of a marine Streptomyces sp. KS3. ${ }^{7)}$ Komodoquinones A (1) and B (2) are characterized as a rare anthracycline having a 9-methyl substituent (e.g. nogalamycin, ${ }^{8)}$ steffinomycin, ${ }^{9)}$ and mutactimycin ${ }^{10)}$ ). The absolute stereo-structure of komodoquinone B (2) with 7,9-syn-dihydroxyl groups has been confirmed by application of the modified Mosher's method. ${ }^{11)}$ The amino sugar portion in $\mathbf{1}$ was also characterized to be linked to the hydroxyl group in the D-ring of anthracyclinone. The NMR analysis of the amino sugar portion elucidated that this amino sugar is the C-4 stereo-isomer of mycaminose, ${ }^{12}$ ) which has been found as a component in macrolide antibiotics, and a novel type of amino sugar. This paper presents the elucidation of the absolute structure of the sugar portion in komodoquinones A (1), the effect of a solid-state medium on the production of $\mathbf{1}$ and $\mathbf{2}$, and the neuritogenic activity of $\mathbf{1}$ against Neuro 2A cells.

\section{Results and Discussion}

In order to determine the absolute stereo-structure of the sugar portion in $\mathbf{1}$, the following chemical conversion was executed. Compound 1 was subjected to $\mathrm{NaIO}_{4}$ degradation followed by acid treatment $\left(2 \mathrm{~N}\right.$ aq. $\mathrm{HCl}$ at $\left.50^{\circ} \mathrm{C}\right)$ to give a C3-aldehyde, which was further treated with phenylhydrazine and acetic acid to furnish 1-(phenylhydrazo)propan2-ol (4c). The authentic hydrazone derivatives $\mathbf{4 a}$ and $\mathbf{4 b}$ were also prepared from methyl L-rhamnoside (3) and methyl D-fucoside (5) applying the same synthetic route (Fig. 2). HPLC analysis of these hydrazone derivatives clarified that 4c was identical with $\mathbf{4 a}$. Therefore, the amino sugar moiety in $\mathbf{1}$ has been defined to be L-form and the absolute stereostructure of komodoquinone A was confirmed to be $\mathbf{1}$ (Fig. $1)$.

Solid-state fermentation is well known to be used for production of brewages, sake, and soy-sauce. In recent years, solid-state fermentation has been applied successfully for production of secondary metabolites. ${ }^{13)}$ Komodoquinones A (1) and B (2) together with staurosporine ${ }^{14)}$ were produced by a marine Streptomyces sp. KS3 cultured in a solid-state medium based on rice. In the case that the KS3 strain was grown in a ISP1+glucose liquid medium, no production of $\mathbf{1}$ and 2 was observed. These results led us to investigate the

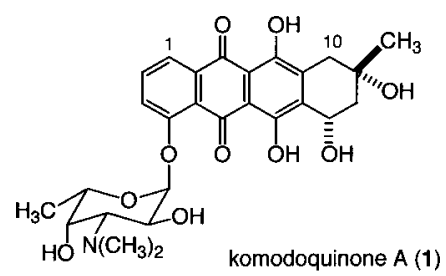<smiles>C[C@]1(O)Cc2c(O)c3c(c(O)c2C[C@H]1O)C(=O)c1c(O)cccc1C3=O</smiles>

komodoquinone B (2)

Fig. 1. Structure of Komodoquinones A (1) and B (2)

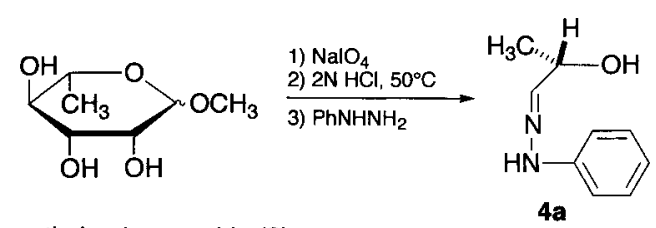

methyl L-rhamnoside (3)
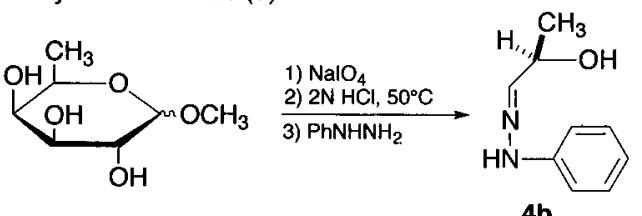

methyl D-fucoside (5)

4b

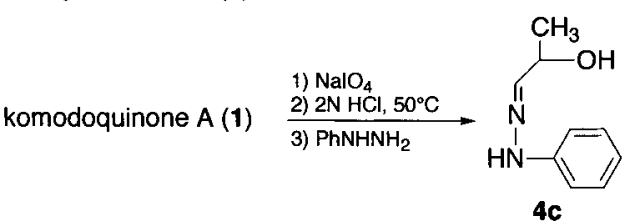

Fig. 2. Hydrazone Derivatives Prepared from Komodoquinone A (1), Methyl L-Rhamnoside (3) and Methyl D-Fucoside (5) 
role of the solid-state fermentation on the growth of the KS3 strain and its ability to produce the secondary metabolites. We examined the effect of other cereals such as corn, soybean, and barley, on the production of $\mathbf{1}$ and $\mathbf{2}$. The solidstate medium based on corn or soybean was not able to support the growth of the KS strain. However, in the case of either barley or rice, the strain grew very well and produced komodoqinones A (1) and B (2). On the other hand, the cultivation of the KS3 strain in ISP1+glucose medium-added rice produced only komodoquinone B (2). Therefore, it was presumed that a constituent contained in barley or rice was concerned with the biosynthesis of the aglycone, komodoquinone B (2), in the fermentation of the KS3 strain. However, the biosynthesis and glycosidation of the amino sugar portion in $\mathbf{1}$ must be associated with the contribution of some parameter such as osmotic pressure, which usually exert a substantial effect in solid-state fermentation. Consequently, solid-state fermentation of microorganisms is expected to be a good strategy to explore novel bioactive compounds.

Many anthracyclines have been reported from terrestrial actinomycetes, which have been documented to exhibit antimicrobial, anti-tumor and other biological activities. ${ }^{15)}$ However, komodoquinone A (1) is the first instance of anthracycline exhibiting neuritogenic activity. Compound $\mathbf{1}$ was shown to induce a morphological change ${ }^{16,17)}$ with multipolar processes emanating from the body of Neuro $2 \mathrm{~A}$ cells at a concentration of $1 \mu \mathrm{g} / \mathrm{ml}$ (Fig. 3). In contrast, adriamycin (6), a repesentative anthracycline, showed no neuritogenic activity even at the same concentration, and komodoquinone B (2), the aglycone of $\mathbf{1}$, showed only weak activity at a concentration of $30 \mu \mathrm{g} / \mathrm{ml}^{7)}$ These results imply that the amino sugar moiety bound to the D-ring in $\mathbf{1}$ might play an important role for neuritogenic activity.

Next, we investigated the effect of $\mathbf{1}$ and $\mathbf{6}$ on the cell cycle of Neuro 2A cells, since neuronal differentiation was closely related to the cell cycle. ${ }^{18)}$ The cell cycle of Neuro $2 \mathrm{~A}$ cells treated with 1 (at $1 \mu \mathrm{g} / \mathrm{ml})$ for $24 \mathrm{~h}$ was arrested at the G1 phase, while that treated with 6 (at $1 \mu \mathrm{g} / \mathrm{ml})$ for $24 \mathrm{~h}$ was arrested at the G2/M phase (Fig. 4). Generally, anthracycline antibiotics, which intercalate in DNA and RNA, have been known to arrest the cell cycle at the G2/M phase. ${ }^{19)}$ Therefore, komodoquinone A (1) may exert neuronal differential activity by a mechanism, which is different from the intercalation in DNA.

\section{Experimental}

The following instruments were used to obtain physical data: a Jasco DIP181 digital polarimeter for specific rotations; a Hitachi 260-30 infrared spectrometer for IR spectra; a Varian Inova-600 $(600 \mathrm{MHz}) \mathrm{NMR}$ spectrometer for ${ }^{1} \mathrm{H}$ - and ${ }^{13} \mathrm{C}$-NMR $(150 \mathrm{MHz})$ spectra. Silica gel (Fuji silysia BW-200) and pre-coated thin layer chromatography (TLC) plates (Merck, Kiesel gel, $60 \mathrm{~F}_{254}$ ) were used for column chromatography and TLC. Spots on TLC plates were detected by spraying vanillin $/ \mathrm{H}_{2} \mathrm{SO}_{4}$ (vanillin $5 \mathrm{~g}, c-\mathrm{H}_{2} \mathrm{SO}_{4}$ $95 \mathrm{ml}$ ) or acidic $p$-anisaldehyde solution ( $p$-anisaldehyde $25 \mathrm{ml}, c-\mathrm{H}_{2} \mathrm{SO}_{4}$ $25 \mathrm{ml}$, acetic acid $5 \mathrm{ml}$, EtOH $425 \mathrm{ml}$ ) with subsequent heating.

Preparation of Hydorazone Derivatives $4 \mathbf{a}-\mathbf{c}$ A solution of methyl Lrhamnoside $(3,80 \mathrm{mg})$ in $\mathrm{MeOH}$-water $(1: 1,5 \mathrm{ml})$ was treated with $\mathrm{NaIO}_{4}$ $(1.4 \mathrm{~g})$ for $12 \mathrm{~h}$ at room temperature, and then the reaction mixture was extracted with AcOEt. The AcOEt layer was washed with brine and dried over $\mathrm{MgSO}_{4}$. Removal of solvent from the AcOEt layer under reduced pressure gave a corresponding aldehyde. A solution of the aldehyde in $2 \mathrm{~N} \mathrm{HCl}$ $(10 \mathrm{ml})$ was stirred for $1 \mathrm{~h}$ at $50^{\circ} \mathrm{C}$. After neutralization by $\mathrm{Na}_{2} \mathrm{CO}_{3}$, the reaction mixture was added to phenylhydrazine $(100 \mu \mathrm{l})$ and a drop of acetic acid. After further $1 \mathrm{~h}$ stirring, the reaction mixture was quenched with brine, then the whole was extracted with AcOEt. The AcOEt phase was
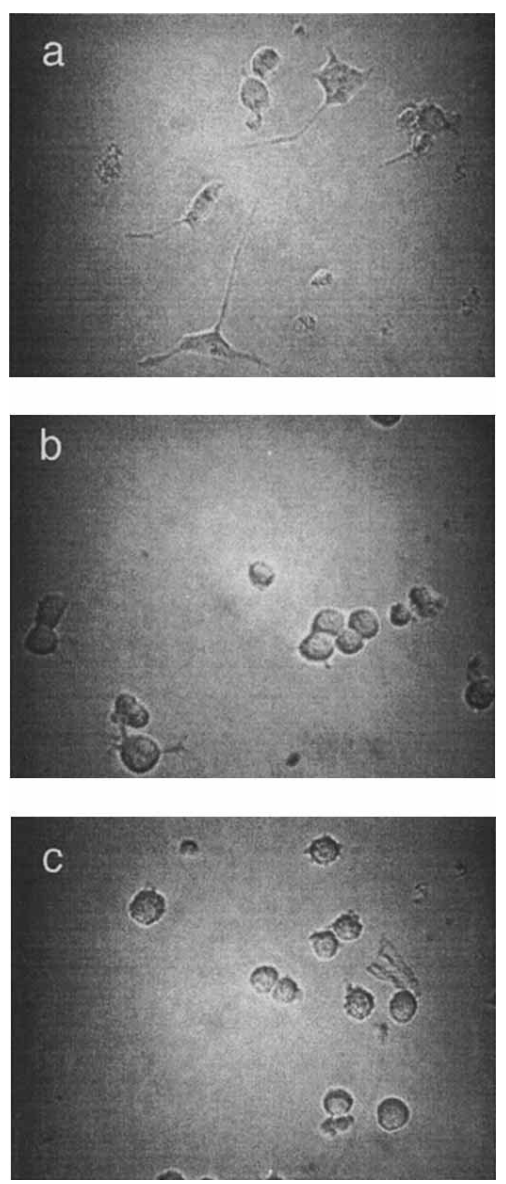

Fig. 3. Photomicrographs of Komodoquinone A (1) and Adriamycin (6)Induced Morphological Changes in Neuro 2A Cells

Cells were cultured in the presence of $1(1 \mu \mathrm{g} / \mathrm{ml}$; a) or $\mathbf{6}(1 \mu \mathrm{g} / \mathrm{ml} ; \mathrm{b})$ or absence (control; c) for $24 \mathrm{~h}$.

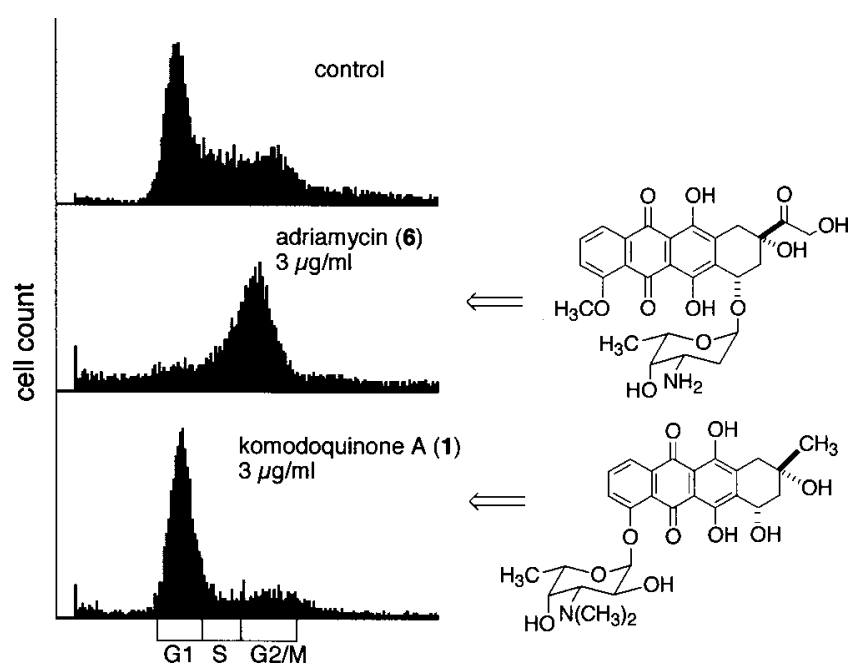

Fig. 4. The action of Komodoquinone (1) and Adriamycin (6) on the Cell Cycle of Neuro 2A Cells

Neuro $2 \mathrm{~A}$ cells were exposed to $\mathbf{1}$ or $\mathbf{6}$ for $24 \mathrm{~h}$, and the cell cycle distribution was determined by flow cytometric analysis.

dried over $\mathrm{MgSO}_{4}$ and evaporated in vacuo. The crude product was purified by reversed phase HPLC [Cosmosil 5C18-AR $(10 \mathrm{~mm}$ i.d. $\times 250 \mathrm{~mm})$, mobile phase; $\mathrm{MeOH}$-water $=7: 3$, detection; $\mathrm{UV}(\lambda=268 \mathrm{~nm})$, flow rate; $2.0 \mathrm{ml} / \mathrm{ml}$ ] to afford $1 R$-(phenylhydrazo)propan-2-ol $\mathbf{4 a}(11 \mathrm{mg})$. A solution of methyl D-fucoside $(\mathbf{5}, 80 \mathrm{mg}$ ) was similarly treated to obtain $1 S$-(phenyl- 
hydrazo)propan-2-ol $\mathbf{4 b}(8 \mathrm{mg})$.

A solution of komodoquinone A $(\mathbf{1}, 4.0 \mathrm{mg})$ in $\mathrm{MeOH}-$ water $(1: 1$, $0.1 \mathrm{ml})$ was treated with $\mathrm{NaIO}_{4}(10 \mathrm{mg})$ for $12 \mathrm{~h}$ at room temperature, and then the reaction mixture was extracted with AcOEt. The AcOEt layer was washed with brine and dried over $\mathrm{MgSO}_{4}$. Removal of solvent from the AcOEt layer under reduced pressure gave a corresponding aldehyde. A solution of the aldehyde in $2 \mathrm{~N} \mathrm{HCl}(0.2 \mathrm{ml})$ was stirred for $1 \mathrm{~h}$ at $50^{\circ} \mathrm{C}$. The reaction mixture was similarly treated to afford 1-(phenylhydrazo)propan-2-ol $4 \mathbf{c}$

Hydrazone Derivative 4a: $[\alpha]_{\mathrm{D}}-53^{\circ}(c=0.2, \mathrm{MeOH})$. IR $(\mathrm{KBr}) \mathrm{cm}^{-1}$ : $3345,1653,1585$. UV $\lambda_{\max }(\mathrm{MeOH}) \mathrm{nm}(\varepsilon): 268$ (8600). ${ }^{1} \mathrm{H}-\mathrm{NMR}$ $\left(600 \mathrm{MHz}, \mathrm{C}_{6} \mathrm{D}_{6}\right) \delta: 7.2-7.0(7 \mathrm{H}, \mathrm{m},-\mathrm{Ph},-\mathrm{NH},-\mathrm{CNH}), 4.15(1 \mathrm{H}, \mathrm{q}$, $J=6.6 \mathrm{~Hz}, 2-\mathrm{H}), 3.87(1 \mathrm{H}, \mathrm{s}, 2-\mathrm{OH}), 1.11(3 \mathrm{H}, \mathrm{d}, J=6.6 \mathrm{~Hz}, 3-\mathrm{H})$. FAB-MS: $m / z 165\left(\mathrm{M}+\mathrm{H}^{+}\right)$. High resolution FAB-MS: $m / z 165.1033\left(\mathrm{M}+\mathrm{H}^{+}\right.$, Calcd for $\left.\mathrm{C}_{9} \mathrm{H}_{12} \mathrm{~N}_{2} \mathrm{O}: 165.1028\right)$.

Hydrazone Derivative $4 \mathrm{~b}:[\alpha]_{\mathrm{D}}+52^{\circ}(c=0.2, \mathrm{MeOH})$. IR $(\mathrm{KBr}) \mathrm{cm}^{-1}$ : $3345,1655,1580$. UV $\lambda_{\max }(\mathrm{MeOH}) \mathrm{nm}(\varepsilon): 268$ (8600). ${ }^{1} \mathrm{H}-\mathrm{NMR}$ $\left(600 \mathrm{MHz}, \mathrm{C}_{6} \mathrm{D}_{6}, \delta\right): 7.2-7.0(7 \mathrm{H}, \mathrm{m},-\mathrm{Ph},-\mathrm{NH},-\mathrm{CNH}), 4.15(1 \mathrm{H}, \mathrm{q}$, $J=6.6 \mathrm{~Hz}, 2-\mathrm{H}), 3.85(1 \mathrm{H}, \mathrm{s}, 2-\mathrm{OH}), 1.11(3 \mathrm{H}, \mathrm{d}, J=6.6 \mathrm{~Hz}, 3-\mathrm{H})$. FAB-MS: $m / z 165(\mathrm{M}+\mathrm{H})^{+}$. High resolution FAB-MS: $m / z 165.1031\left(\mathrm{M}+\mathrm{H}^{+}\right.$, Calcd for $\mathrm{C}_{9} \mathrm{H}_{12} \mathrm{~N}_{2} \mathrm{O}: 165.1028$ )

Chiral HPLC Analysis of Hydrazone Derivatives $4 a-c$ Hydrazone derivatives $\mathbf{4 a}-\mathbf{c}$ were analyzed by chiral HPLC [CHIRALCEL OD-R, $4.6 \mathrm{~mm}$ i.d. $\times 250 \mathrm{~mm}$, mobile phase; $\mathrm{CH}_{3} \mathrm{CN}-\mathrm{H}_{2} \mathrm{O}=3: 7$, detection; UV $(268 \mathrm{~nm})$, flow rate; $0.5 \mathrm{ml} / \mathrm{min}]$. The retention times of $4 \mathbf{a}-\mathbf{c}$ were 34.5 , 30.0 , and $34.5 \mathrm{~min}$, respectively

Culture of Streptomyces sp. KS3 in Other Conditions A liter of seed medium (ISP1+glucose) [5 $\mathrm{g}$ of Bacto triptone, $3 \mathrm{~g}$ of yeast extract, $5 \mathrm{~g}$ of glucose, and artificial sea water] was autoclaved before use. The rice solid medium [25 g of rice, $200 \mathrm{mg}$ of glucose, $100 \mathrm{mg}$ yeast extract, and $50 \mathrm{ml}$ of artificial sea water] in $500 \mathrm{ml}$ flask was autoclaved before use. The barley solid medium [ $15 \mathrm{~g}$ of barley, $200 \mathrm{mg}$ of glucose, $100 \mathrm{mg}$ yeast extract, and $30 \mathrm{ml}$ of artificial sea water] in $500 \mathrm{ml}$ flask was autoclaved before use. The soybean solid medium [ $25 \mathrm{~g}$ of soybean, $200 \mathrm{mg}$ of glucose, $100 \mathrm{mg}$ yeast extract, and $40 \mathrm{ml}$ of artificial sea water] in $500 \mathrm{ml}$ flask was autoclaved before use. The corn solid medium [25 g of corn, $200 \mathrm{mg}$ of glucose, $100 \mathrm{mg}$ yeast extract, and $40 \mathrm{ml}$ of artificial sea water] in $500 \mathrm{ml}$ flask was autoclaved before use. A liter of ISP $1+$ glucose-rice medium $[25 \mathrm{~g}$ of rice, $5 \mathrm{~g}$ of Bacto triptone, $3 \mathrm{~g}$ of yeast extract, $5 \mathrm{~g}$ of glucose, and artificial sea water] was autoclaved before use. The Streptomyces sp. KS3 starin was cultured in the seed medium at $30^{\circ} \mathrm{C}$ for $5 \mathrm{~d}$. Then, the broth of the strain was inoculated into the production medium and cultured under static conditions at $30^{\circ} \mathrm{C}$ for 2 weeks.

Assay for Neuritogenic Activity in Neuro 2A Cells Neuro 2A cells were grown in Dulbecco's modified essential medium (DMEM) with $10 \%$ fetal bovine serum (FBS). The cells were kept in an incubator at $37^{\circ} \mathrm{C}$ with $5 \% \mathrm{CO}_{2}$. The cells were plated on 24-well plates at a density of $2 \times 10^{4}$ per well with $1 \mathrm{ml}$ of culture medium. After $24 \mathrm{~h}$ cultivation, the medium was exchanged for fresh medium, and the testing sample as $10 \mu \mathrm{l}$ of EtOH solution was added to each well. After 24 or $48 \mathrm{~h}$ incubation, morphological changes in the cells were observed under microscope.
Cell Cycle Analysis The cell suspension of Neuro 2A cells $\left(4 \times 10^{4}\right.$ cells in $1 \mathrm{ml}$ of the culture medium) was plated on 24-well plate and incubated for $24 \mathrm{~h}$. After medium exchange, an ethanol solution $(10 \mu \mathrm{l})$ of the test sample was added and further incubated for $24 \mathrm{~h}$. The culture medium of the cell suspension was removed by centrifugation ( $1000 \boldsymbol{g}$ for $3 \mathrm{~min})$. The collected cells were dyed by DNA-Prep Reagents Kit for $20 \mathrm{~min}$. Then, the supernatant was removed by centrifugation $(500 \mathrm{~g}$ for $5 \mathrm{~min})$ and the resulting cell suspension in $500 \mu \mathrm{l}$ of D-PBS (-) solution was filtered by $40-\mu \mathrm{m}$ nylon mesh filter. The cell cycle analysis of the filtrate was carried out on a FACSCalibur (Becton Dickinson, $\lambda_{\mathrm{ex}}=493 \mathrm{~nm}, \lambda_{\mathrm{em}}=630 \mathrm{~nm}$ ).

Acknowledgments The authors are grateful to the Houansha Foundation, the Tokyo Biochemical research foundation, and the Uehara Memorial Foundation for financial support

\section{References}

1) Jensen P. R., Fenical W., "Drug from the Sea," ed. by Fusetani N., Karger, Basel, 2000, pp. 6-29.

2) Jensen P. R., Fenical W., Annu. Rev. Microbiol., 48, 559-548 (1994).

3) Jensen P. R., Fenical W., J. Ind. Microbiol., 17, 346-351 (1996).

4) Pietra F., Nat. Prod. Rep., 14, 453-464 (1997).

5) Kobayashi M., Higuchi K., Murakami N., Tajima H., Aoki S., Tetrahedron Lett., 38, 2859-2862 (1997).

6) Aoki S., Yoshioka Y., Miyamoto Y., Higuchi K., Setiawan A., Murakami N., Chen Z., Sumizawa T., Akiyama S., Kobayashi M., Tetrahedron Lett., 39, 6303-6306 (1998).

7) Itoh T., Kinoshita M., Aoki S., Kobayashi M., J. Nat. Prod., 66, 1373-1377 (2003)

8) Wiley P. F., Kelly R. B., Caron E. L., Wiley V. H., Johnson J. H., MacKellar F. A., Mizsak S. A., J. Am. Chem. Soc., 99, 542-549 (1997).

9) Kunnari T., Tuikkanen J., Hautala A., Hakala J., Ylihonko K., Mantsala P., J. Antibiot., 50, 496-501 (1997).

10) Speitlin M., Nattewan P., Yazawa K., Mikami Y., Wollny I., Ritzau M., Laatsch H., Grafe U., J. Antibiot., 51, 693-698 (1998).

11) Ohtani I., Kusumi T., Kashman Y., Kakisawa H., J. Am. Chem. Soc., 113, 4092- 4096 (1991).

12) Omura S., Nakagawa A., Neszmelyi A., Gero S. D., Sepulchre A., Piriou F., Lukacs G., J. Am. Chem. Soc., 97, 4001-4009 (1975).

13) Robinson T., Singh D., Nigam P., Appl. Microbiol. Biotechnol., 55, 4284-4289 (2001)

14) Martinsson T., Fowler C. J., Life Sci., 53, 1557-1565 (1993).

15) Demain A. L., Appl. Microbiol. Biotechnol., 52, 455- 463 (1999).

16) Blanco V., Camelo J. L., Carri N. G., Cell Biol. Internat., 25, 909917 (2001)

17) Fenteany G., Schreiber S. L., J. Biol. Chem., 273, 8545-8548 (1998).

18) Aoki S., Matsui K., Tanaka T., Wei H., Kobayashi M., Biochem. Biophys. Res. Commun., 289, 558-563 (2001).

19) Kimler B. F., Schneiderman M. H., Leeper D. B., Cancer Res., 38 , 809-814 (1978). 